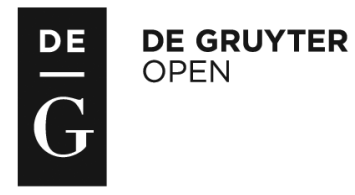

Administration, vol. 63, no. 1 (2015), pp. 73-77

doi: 10.1515/admin-2015-0006

\title{
The Value(s) of Civil Leaders: A Study into the Influence of Governance Context on Public Value Orientation
}

Steven de Waal (The Hague: Eleven International Publishing; 2014; ISBN: 978-9-462364-59-2; 274 pp; €37.50)

Civil leadership, which is distinguished from public leadership and traditional philanthropy, functions in the realm beyond civil society. It is characterised by a sense of urgency about societal needs and the commitment to address them. Civil leaders who function as 'innovators' - often in response to perceived failures of government services and regulation - can be located in private market-based organisations as well as semi-public, or 'third sector', organisations ( $p$. 34). Consequently, civil leaders are different to 'civic' leaders, who are found in community, associational and volunteering domains. Civil leaders are defined as 'men and women not holding public office who involve themselves in solving societal problems and seeking to create public impact by making use of their entrepreneurial, organisation building and/or political skills' (p. 15).

In The Value(s) of Civil Leaders de Waal sets out to answer the following questions: 'what values motivate and direct civil leaders and to what extent are these values shaped by the institutional context in which civil leaders operate?' A former civil servant and member of the National Executive Committee of the Dutch Labour Party, de Waal is the founder and current chairman of Public SPACE Foundation, a private, non-profit think tank aimed at stimulating social entrepreneurship and active citizenship.

The book's main thesis is that social value systems - that is, personal views on the best possible living for other or all people in a societal and institutional context - act as drivers and motivators for civil leaders (p. 39). Values have long been considered by many social theorists as important to our understanding of attitudes and behaviour 
(Schwartz, 2011). They are often characterised as a kind of 'glue' that binds together attitudes and beliefs, and serves as a set of guiding principles in people's lives. There is growing empirical literature identifying the values of citizens and analysing their relationship with behaviour (Inglehart, 2010; Schwartz et al., 2010; Vecchione et al., 2015). This book focuses on the role of values in bringing about and guiding civil leadership, and seeks to discover what influences, drives and focuses civil leaders in modern governance.

The book is divided between two main theoretical and empirical parts. The theoretical section of the book provides the complex conceptual framework for analysis. The framework developed consists of five elements: the habitat of civil leaders and four concepts - values, leadership, social outcomes and governance context - developed in Chapters Two, Three and Four. This includes a typology designed to clarify the relationship between values and three separate governance domains: for-profit versus non-profit, formal versus informal, and public versus private. From this, three 'ideal types' of private governance context are proposed: 'for-profit enterprise, non-profit organization, and the active citizen' (pp. 73-5).

The author's arguments concerning the weaknesses in the existing literature and the need to develop a new conceptual framework to engage in a robust analysis of civil leadership are persuasive. Moreover, the justification of the framework provided is strengthened by the comprehensive and in-depth review of the literature throughout the three conceptual chapters.

Chapter Two provides a thorough theoretical discussion of civil society in order to identify the 'habitat' of civil leaders. Chapter Three examines values and leadership. In terms of values, de Waal focuses on the social value systems of civil leaders and attempts to locate their 'moral compass' or normative core. Values are defined as 'concepts or beliefs about desirable end states or behaviours that transcend specific situations, guide selection or evaluation of behaviour and events, and are ordered by relative importance' (p. 48). Chapter Four examines the formal organisational structure and informal circle found around civil leaders, and develops the concept of the 'meso-governance' level to reflect the importance of values to civil leadership, something not recognised in the existing corporate governance literature (p. 66). This unique governance context, de Waal argues, provides civil leaders with a network and resources, and exerts a normative influence on them (p. 69). 
The second part of the book presents the empirical material via a combination of a comparative multi-case study of thirty civil leaders and two comparative surveys focused on individual value patterns and their possible antecedents in the meso-governance context (p. 106). The case studies are designed to analyse the behaviour and functions of civil leaders while the surveys are designed to explore the relationship between values, governance types and civil leadership. One of the survey questionnaires instructs the thirty interviewed civil leaders to rank values. The second questionnaire was distributed to a wider population of actors not considered 'civil leaders' but with experience of leadership in various meso-governance contexts. The rationale and method for this study is clearly and lucidly presented in Chapter 5.

Chapter 6 presents the findings of the comparative case studies of the thirty civil leaders. The studies' findings are interesting and not always supportive of the initial hypotheses. The case studies reveal the role of values not only as a driver and motivator but as a practical instrument. Values therefore are used as a means to legitimate the role and strategy undertaken by civil leaders in the public domain, to convince people of their good intentions and to foster public support (p. 130-1). Chapter 7 focuses on the relationship between values and the governance context. The findings reveal that the proposed relationship between the values of civil leaders according to each meso-governance type is small, and less important than initially hypothesised. The civil leaders in the study, the author concludes, largely sail by their own moral compass (p. 182).

Arguably, a number of issues within the design of the study reduce its explanatory power. It is unclear whether those interviewed in the case studies are a representative sample of civil leaders in the Netherlands. Moreover, only Dutch civil leaders are surveyed and it is possible that the unique governance context of the Netherlands means the study is not generalisable to other states. For example, this is relevant in relation to the data concerning the 'value patterns' of the different meso-governance contexts. In terms of the not-for-profit domain, the analysis reveals no dominant value or strong cultural pattern (pp. 168-9).

However, it is possible the unique context of the not-for-profit sector in the Netherlands impacts these findings. In contrast to many other countries, the Dutch non-profit sector operates under strict government supervision and regulation. Its non-profit organisations are more public or state-like in character (p. 170). Consequently, it is 
difficult to determine whether the values found through the web survey are typical of a not-for-profit ethos or a consequence of the rather unique context in the Netherlands. These issues are acknowledged by the author, and it is clear that a similar study in other states could begin to build a more robust assessment of the values of civil leaders.

A number of formatting errors and typos are evident within the text, and greater care could have been taken with proofreading and publishing the manuscript. Arguably readers would benefit from the availability of the appendices, which provide more detail on the case studies, within the manuscript. Instead, the appendices are available and published online.

Nonetheless, by bridging normative and empirical methods, The Value(s) of Civil Leaders makes a significant contribution to our understanding of the role and values of civil leadership in the Netherlands. The book's main conclusions are that civil leaders display a common value pattern and possess a distinctive combination of market sector and civil society values ('a civil leadership ethos'), including entrepreneurial spirit, freedom of choice, solidarity and social justice. Doubt is also cast on the relationship between the governance type or background and the individual values of civil leaders. In addition to the empirical findings, the conceptual framework developed furthers our understanding of civil leadership and its role in modern governance and society. Outside the sphere of civil leadership the book is also likely to be of interest to those interested in examining the relationship between values and behaviour in a governance context. Admirably, in the final chapter the author reflects upon the conceptual framework developed in light of the empirical results of the study and, in doing so, makes a good case for the potential of normative and empirical methods to mutually enrich, inform and benefit each other.

\section{Cian Finn}

University of Limerick

\section{References}

Inglehart, R. (2010). Mapping global values (2006). In H. Lune, E. S. Pumar, \& R. Koppel (Eds), Perspectives in social research methods and analysis: A reader for sociology (pp. 203-19). Thousand Oaks, California: Sage. 
Schwartz, S. H. (2011). Studying values: Personal adventure, future directions. Journal of Cross-Cultural Psychology, 42, 307-19.

Schwartz, S. H., Caprara, G. V., \& Vecchione, M. (2010). Basic personal values, core political values, and voting: A longitudinal analysis. Political Psychology, 31, 421-52.

Vecchione, M., Schwartz, S. H., Caprara, G. V., Schoen, H., Cieciuch, J., Silvester, J., ... Alessandri, G. (2015). Personal values and political activism: A cross-national study. British Journal of Psychology, 106, 84-106. 